\title{
'NOT ANOTHER HIJ AB ROW': New conversations on gender, race, religion and the making of communities
}

\section{Transforming Cultures eJ ournal, Vol. 2 No 1, November 2007 http:// epress.lib.uts.edu.au/journals/TfC}

\section{Guest editors’ introduction by Tanja Dreher \& Christina Ho}

Headscarves in schools. Sexual violence in Indigenous communities. Muslim women at public swimming pools. Polygamy. Sharia law. Outspoken Imams on sexual assault. Integration and respect for women. It seems that around the world in the media and public debate, women's issues are at the top of the agenda. Yet all too often, support for women's rights is proclaimed loudest by conservative politicians intent on policing communities and demonising Muslims during the 'war on terror'. This edition of the Transforming Cultures eJournal offers critical reflections on the contemporary politics of gender, race and religion, and provides a platform for those perspectives which are too often sidelined in the debate, perspectives that seek to go beyond simplistic debates such as 'hijab: to ban or not to ban?' or 'Muslim women: oppressed or liberated?'

While 'hijab debates' occur in various guises in France, the Netherlands, Germany, the UK and elsewhere, questions of gender, race and religion have a particular pertinence in Australia, where a combination of recent events has generated unprecedented public and scholarly attention on sexual violence, 'masculinist protection', and ideas of the nation. A moral panic around 'ethnic gang rapes' in 2001, the Cronulla riot of 2005, Sheik Hilaly's comments on 'uncovered meat' in 2006 and the federal government's intervention in the Northern Territory in 2007, all provide a unique opportunity to critically examine how notions of gender, race and religion are at the core of current debates about diversity, cohesion and change in contemporary societies. In contrast to politicians and commentators who often simply assert that 'tolerance' and women's equality have been achieved in Australia, the papers here demonstrate ongoing struggles and innovation at the intersection of antiracism and feminism. 
The collection arises out of a conference we organized in December 2006 at the University of Technology, Sydney, entitled Not Another Hijab Row: new conversations on gender, race, religion and the making of communities. We decided to hold the conference because, despite a decade of 'race debates' in Australia, analyses of the intersections between gender, race and religion remain all but absent in the public sphere. In recent years Muslim women in particular have been subjected to intense public scrutiny, yet these controversies have largely been limited to provocative comments on the hijab and sharia law. These narrow debates have served to silence the experiences and the concerns of Muslim women and of scholars and community workers who engage the intersections of gender, race and religion.

The conference sought to establish a space for constructive dialogue around the perspectives which are marginalised in public discussions, focusing on how gender, race and religion shape notions of belonging and exclusion in Australia. Ideas around gender, race and religion have long been deployed in the construction of national identity, and are particularly evident in current representations of 'aggressive' and 'misogynistic' Islam as the ultimate alien other in 'tolerant' Judeo-Christian Australia. In minority communities, questions over community leadership, representation, and responses to racism have often revolved around constructions of culture, faith and gender roles. We sought papers and presentations from all disciplinary perspectives in order to build a conversation across spectra of belief, scholarship and community.

This interest developed through the ongoing work of the two conference organisers, Dr Tanja Dreher and Dr Christina Ho, both of the University of Technology, Sydney. In research on Muslim women and the media and on Muslim women's networks, the organisers found a need for 'safe spaces' to discuss issues of gender, race and religion, as women's rights had been 'hijacked' in public debate (Ho 2007) and Muslim women struggled to be heard on their own terms in the media (Dreher 2003, 2006).

\section{Why 'Not Another Hijab Row'?}

The title provoked many comments and questions in the lead up to the conference. The most obvious question was - why not another hijab row? What's the problem? Weren't we censoring legitimate debate? In fact the program included a number of very 
interesting papers addressing perceptions and experiences around Muslim women’s covering. Our aim was not to 'censor' any mention of the hijab - as if we even could! but rather to suspend, for a short time, the intense focus on this one particular item of clothing, significant though it is. One of the great ironies is that the more public debate fixates on the hijab, the less space there is for Muslim women to talk about the range of issues that affect their lives (see Hussein in this volume). Rather than censoring, the title was intended to signal a shift in emphasis and a space for conversations that are not limited by the simplistic terms of so much public debate.

Another common question - was this to be a conference about Muslim women? And why were we, two non-Muslim women, organising it? While the conference was intended to make a space for a diversity of Australian Muslim women's perspectives and experiences, it was not intended as a conference specifically for or about Muslim women. For one thing, we were very aware that Muslim women in Australia regularly organise all manner of events and conferences. As organisers we understood our role as summed up in the subtitle - new conversations on gender, race, religion and the making of communities. While Muslim women are currently under intense scrutiny, it is only fitting that questions around Islam and gender should occupy a prominent position in such a conference. But our overall agenda was a wider one, and we were very excited to see the range of papers exploring issues around gender, nationalism, the secularreligious divide, the politics of community and antiracism and interfaith work.

These are difficult times for those working at the intersection of gender and race. Too often the media framing of events such as a Muslim cleric's comments on sexual assault or violence against women in Indigenous communities forces an intractable dilemma: to defend communities experiencing racism is to be read as condoning violence against women. With this conference we aimed to open up a space where the complexities of these issues could be discussed. We were pleased at the number of papers that took up the challenge to develop intersectional analyses - bringing together analyses of gender, race, religion and community. So we aimed to provoke new conversations rather than tired old debates, and to create a space for those voices that are so often marginalised in Australian public debate - be they the voices of Muslim women, of critical feminism or of those working with intersectional analyses and those who refuse essentialising constructions of tradition and community. 


\section{Challenges for contemporary antiracism}

The cover image reflects something of the impetus for the timing of the Not Another Hijab Row conference, on the first anniversary of the Cronulla riot. The image shows a silent protest conducted at an anti-racism rally held in the weeks directly after the riot in December 2005. The image of flag-draped heads was inspired by the work of Sydney artists in the boatpeople.org project. Suvendrini Perera has analysed the image in her reflections on the 'racial terror' enacted at Cronulla (2006: par 65).

'Here the multiple functions of the flag, as hood, blindfold, weapon, threat and disguise were put on display. Through its staging of the ways in which the flag is mobilized as a racial and ethnonational emblem of exclusion, the performance powerfully elucidates the 'strange' responses of opposition and 'ethnic dislike' that the flag provokes. 'Regular', that is, seemingly neutral and unmarked, identities such as 'the ordinary Australian' and the 'patriotic citizen' are called in question as the racial assumptions implicit in them are uncovered. It is only in such courageous expressions of dissent in a climate of racist resurgence that the face of white terror is - fleetingly but unforgettably - exposed.'

For one of us (Dreher), as a participant in the protest action, the experience was another instruction in the politics of representation and the dilemmas of contemporary antiracism work. We spent considerable time in tying the flags to ensure that they would not be read as hijab. Given previous experiences of misrepresentation, participants were wary of media attention and a decision was taken to make no comment to journalists or to onlookers. We toyed with titles for the image - 'See no evil, Hear no evil, Speak no evil'? 'Blind nationalism or blind faith'? 'Does my head look big in this?' In the end we decided against a title - no simple words or sound bite could capture the complex and differing motivations of those who took part in the action.

The silent protest did attract considerable media attention, featuring in most mainstream media coverage of the rally and some international outlets. Much to our horror, Sydney's tabloid, The Daily Telegraph added the caption, 'veiled protest', a reminder of the mainstream media's obsession with the image of the 'veiled woman' and an inability to recognise the protest directed at the white supremacy and masculinist violence on display at Cronulla. Weeks later the image was captioned as a photo of rioters at Cronulla in the letters pages of the Illawarra Mercury. While the Editor apologized privately, these misappropriations of the image suggest something of the challenges of developing creative antiracism work in contemporary Australia. Protest actions, public debates and community-level projects operate in the context of a 
sustained retreat from both the language and policies of antiracism (see Ho and Dreher 2006). While the mainstream media has been a crucial forum for a decade of 'race debates' in Australia, it is extremely difficult to mobilise irony or a complex politics of representation within the news media (see Dreher 2003).

Despite the recurring attention to hijab in media and public debate, nuanced discussion is remarkably rare. It is not surprising that the hijab or veil has become such a contested symbol in the current climate of fear and hostility towards Muslims. As Bouma and Brace-Govan (2000: 168) write, 'This external bodily expression of an internally held religious faith runs counter to Australian social expectations that religiosity is a private affair and should be kept out of the public arena.'

In particular, the veiled woman has been the key symbol of the anxiety over Islam's 'oppression of women'. After September 11, images of veiled women reached 'epic proportions' (Ayotte and Husain, 2005: 117), as the American crusade against Al Qaeda became gradually a mission to 'liberate' Afghan women. During the invasion of Afghanistan, the veil became a powerful 'visual and linguistic signifier of Afghan women's oppression' (Ayotte and Husain, 2005: 117), supposedly encapsulating all that was wrong about the Taliban. Of course, this was simply the latest manifestation of a long tradition dating to colonial times, when Western concerns about the status of women within Islam frequently served as a moral justification for European colonialism in the Middle East.

Yet, as Muslim and other scholars have comprehensively shown, the hijab cannot be reduced to a simplistic symbol of oppression. Rather, veiling practices among Muslim women have always reflected complex arrays of religious, personal, political and national affiliations. From Egypt and Algeria to France, Germany and beyond, women’s decisions to veil have historically symbolised allegiances, anxieties, oppositions and identities in broader contexts of colonialism, modernisation, globalisation and change (Abu Odeh 1993; Ahmed 1992; McLeod 1992; Timmerman 2000). ${ }^{1}$

\footnotetext{
${ }^{1}$ MacLeod traces the 'new veiling' in the Islamic world to the 1970s, a movement 'initiated as a political and religious statement in the universities after the 1967 and 1973 wars with Israel' (1992: 541), and which, over the years, has been taken on different meanings 'from country to country, class to class, even individual to individual' (1992: 540).
} 
At a more micro level, research on particular Muslim women's veiling practices has shown how the adoption of a pious identity can be used as a creative means for carving out greater personal freedom within family and community contexts. For example, studies have shown how young South Asian women in the UK appeal to Islamic scriptures about the importance of education and women's rights in marriage to justify their desires to seek higher education or professional careers. As Butler (1999: 147) argues, 'These women are using Islam as a tool to question traditional culture' (see also Dwyer 2000; Samad 2004).

In Australia, Muslim women have been keen to defend the decision to wear the hijab as a free choice, women's own strong and independent expression of religious faith and community affiliation. For example, one of the most prominent public campaigns of the Sydney-based United Muslim Women Association in recent years has been its 'prohijab campaign', which defends the right to wear a headscarf as a basic human right under freedom of religion (UMWA 2005). As Shakira Hussein notes in her paper, such efforts have been successful in gradually shifting public opinion on the hijab. A decade ago, the idea of veiling as a woman's free choice would not have been accepted in 'mainstream' Australia, whereas now, it is a relatively commonplace (though by no means universally accepted) argument.

However, Hussein's paper in this edition of Transforming Cultures argues that simply presenting the hijab as a 'choice' is insufficient, because it traps discussions within a simplistic dichotomy of 'force' versus 'choice'. In the face of prevailing assumptions in Western societies that Muslim women are 'forced' to veil, Hussein notes that it is understandable that Muslim women have responded by asserting that veiling is their 'choice'. However, she argues that neither position genuinely captures the more complex reality of women's dress code decisions, which are usually more about 'negotiated compromised positions'.

Moreover, an unanticipated consequence of the defence of the hijab has been to reinforce its position as a symbol of 'authentic' Muslim womanhood, thereby marginalising the role of non-hijabis. Hussein draws on her own experience as a Muslim commentator, who has been asked by journalists to don a hijab for the sake of the camera. Presumably she is less than a fully authentic Muslim without one. In the face of 
these pressures, Hussein wonders how she can support her fellow Muslims' right to veil without simultaneously presenting the hijab as the marker of 'true' Muslim identity. This is an important contribution to our understanding of the complexities of one of the most essentialised and overburdened cultural symbols of our time.

\section{The 'new politics of gender'}

Hijab debates are a crucial component of a contemporary politics of gender operating during the 'war on terror' in the United States (Ferguson and Marso 2007) and in Australia (Ho 2007). The key feature of this new politics of gender is the hijacking of women's rights and the use of feminised rhetorics to justify the 'war on terror' coupled with policies which constrain women's role under the rubric of 'family values'. The new politics supports particular interpretations of 'women's rights', but is far from feminist in that it is grounded in a conservative gender ideology which 'characterizes men as dominant, masculine protectors and women as submissive, vulnerable, and therefore deserving of and in need of men's respect' (Ferguson and Marso 2007: 5). While focusing on the now waning Presidency of George W Bush, Ferguson and Marso argue that Bush's 'constellation of an eviscerated liberal feminism, a hierarchical gender ideology, and a neoconservative security strategy' represents a new politics of gender which will have continued significance and impact for many years to come.

Iris Marion Young offers perhaps the most compelling analysis of the 'logic of masculinist protection' at work in the current security state and the 'war on terror'. Rather than understanding masculinity as selfish, aggressive and domineering, 'central to the logic of masculinist protection is the subordinate relationship of those in the protected position. In return for male protection, the woman concedes critical distance from decision-making autonomy' (Young 2007: 119). For Young, the current US security state is a 'protection racket' founded on a tradeoff between protection and subordinated citizenship. In the 'war on terror', the logic of masculinist protection is used to justify US military interventions, most notably in the argument that Afghan women would be 'saved' through the invasion of Afghanistan.

While the US analyses have focused on the position of Muslim women 'over there' in need of saving and protection, and Afghan women in particular, the new politics of gender in Australia has focused intense scrutiny on Muslim women within (Ho 2007). 
Australian Muslim women have found themselves at the centre of numerous public debates and controversies - from hijabs in schools to access to public swimming pools and recurring debates around Islam and violence against women. Muslim women have become highly visible but have also found it extremely difficult to shift news agendas and to be heard on their own terms (Dreher and Simmons 2005).

The apparent concern for the rights of Muslim women in Australian public discourse is interestingly mirrored by an anxiety about the victimisation of white Australian women, whether via sexual harassment, assault, or most sensationally of all, 'ethnic gang rape'. At the centre of this debate is the figure of the threatening 'young Muslim man', a topic that Kiran Grewal, in this issue, tackles in her analysis of the public discussion of the Sydney gang rapes and the 2005 Cronulla riots. Grewal argues that the portrayal of the gang rapes racialised these crimes, presenting them as Muslim attacks on the Australian community, rather than assaults on individual women.

This discourse has enabled the articulation of a paternalistic nationalism defined in opposition to a 'misogynistic' and 'oppressive' Islam, that both oppresses its own women, and now threatens 'our' (read: white) women. In this context, sexual assaults committed by young Muslim men are attacks on Australia and its values, in stark contrast to the less hostile portrayal of similar allegations against Australian sporting heroes. Likewise, during the Cronulla riots, white Australian participants were simply 'boozed up boys behaving badly', while Lebanese and Muslim participants were ‘waging war' against Australia.

Kiran Grewal's piece in this collection is a timely contribution to a growing body of Australian literature analysing the racialisation of crime and criminalisation of race (see especially Collins et al 2000 and Poynting et al 2004). It also offers an important gendered analysis of these debates, which is often under-acknowledged. Clearly, ideas about masculinity and femininity intertwine in crucial ways with those about race and culture to produce a discourse of white masculine protection of vulnerable women at risk from the 'enemy' masculinity of the non-white other.

Anxiety over threats to 'white women' were exemplified in a 'Bikini March' planned to mark the Cronulla anniversary in Melbourne on the same weekend as the Not Another 
Hijab Row conference. If the 'flagheads' protest in 2005 demonstrates something of the limits of antiracism in public debate, 'The Great Australian Bikini March' planned for 2006 was a stark reminder of the centrality of gender in contemporary struggles around 'Australian values', immigration and border protection. The march was called as a protest against earlier comments, widely debated in the media, by Sydney Sheik Hilaly describing immodestly dressed women as 'uncovered meat' inviting sexual assault. The organizer described herself as a 'bikini-wearing grandma' and urged women to march in bikinis to the Islamic Information and Support Centre in Melbourne, calling for the deportation of Sheik Hilaly and Melbourne’s Sheik Omran as well as ‘urgent citizenship legislation'. White supremacist groups quickly joined the campaign, arguing that women's safety was under threat from 'extremist Muslim attitudes' towards women and sexual assault. They said, 'we must now stand together on this issue, regardless of what other issues we might have, to ensure Australia's wives, mothers, daughters and sisters feel safe in their own country'. After discussions with Victoria Police and with a number of community organizations, the march was cancelled. At the Not Another Hijab Row conference, Joumanah el-Matrah of the Islamic Women's Welfare Council reported on the negotiations with the march organizer and the community BBQ and mosque open day against racism and sexual assault held at the Islamic Information and Support Centre on the day of the planned march.

The theme of racialised protection of women is productively juxtaposed alongside an analysis of the political uses of secularism in Holly Randell-Moon's paper in this issue, 'Secularism, feminism and race in representations of Australianness'. Randell-Moon powerfully dissects the political discourse of the Howard Government, to show how its combination of 'Australian values' with secularism and gender equality allow it to demonise Islam and Muslims as backward and misogynist.

Drawing on Ferguson's analysis (2005) of the Bush Administration's 'feminised security rhetoric', which justifies the 'war on terror on the basis of defending women's rights in Iraq and Afghanistan, Randell-Moon argues that the Howard Government has developed a similar discourse of 'feminised mainstream values' that pits 'mainstream' white Australia as the defender of gender equality. Under this logic, in contrast to Muslim societies, Australia has advanced away from pre-modern values towards a secularism founded on reason, freedom and equality. These are the values threatened by 
an aggressive Muslim minority determined to live according to an alternative, backward belief system.

However, as Randell-Moon reminds us, the depiction of Australia as a secular society elides its Christian heritage and moreover, the growing influence of a particular politicised strain of Christianity within the corridors of power in this country. And of course, the portrait of Australian values as founded on freedom and equality is only possible when accompanied by a denial of the Australian nation's own foundations on colonial relations of oppression.

The intersection of secularism and 'Australian values' is further explored in Sophie Sunderland's innovative critique of the work of Spirituality Studies academic, David Tacey. An advocate of what he terms 'post-secular spirituality', Tacey argues for a spiritual renewal through an embracing of the Australian landscape and Aboriginal cultures and has been taken up in popular debates around Australian national identity, particularly under the Keating government. Where scholars have previously critiqued Tacey's constructions of Aboriginality, Sunderland turns her attention also to the construction of whiteness in Tacey’s work. Through a close reading of Tacey's work, Sunderland demonstrates that the 'empty' whiteness posited by Tacey in fact functions as a position of power in a neo-colonial politics which closes off a post-colonial 'spacebetween'. In this reading, the 'spiritual' emerges as a universalistic, Euro-centric and Judaeo-Christian model which positions Aboriginal people as responsible for the ‘salvation' of non-Aboriginal Australians.

Sunderland's distinctive contribution to the debates around secularism, spirituality and the nation stems from her engagement with the rapidly developing literature in whiteness studies in Australia. Aileen Moreton-Robinson argues for a 'new research agenda' (2006) which addresses issues of Indigenous sovereignty and the possessive logic of whiteness beyond the ‘judicio-political framework’ usually assumed by legal scholars and political theorists. Drawing on Foucault, Moreton-Robinson asks:

'to what extent does White possession circulate as a regime of truth that simultaneously constitutes White subjectivity and circumscribes the political possibilities of Indigenous sovereignty. How does it manifest as part of common-sense knowledge, decision-making and socially produced conventions and signs?' (2006: 389) 
Sophie Sunderland's analysis of David Tacey's 'post-secular spirituality' falls within such a research agenda, exploring the ways in which an 'embrace' of Aboriginal spirituality can serve to mask Indigenous sovereignties and to continue investment in white possession of the nation.

Indigenous sovereignty is at the core of Fiona McAllan's article on the politics of ‘community' underpinning federal Indigenous Affairs policy as exemplified in Native Title decisions and the 2007 'intervention' in Northern Territory Aboriginal communities. McAllan's interrogation of the possessive logic of patriarchal whiteness as analysed by Moreton-Robinson and Irene Watson is framed by the notion of community as sharing incommensurable difference and productive disagreement developed by Jean-Luc Nancy and later Linnell Seccomb. Through the Yorta Yorta Native Title decision and the Northern Territory intervention McAllan traces the continuing operations of colonial dispossession and property relations through the Crown such that 'Indigenous dispossession remains the groundwork' of the law and the nation. Crucial to this continuing dispossession are the difficulties in proving 'community' and of recognising communal ownership under common law.

In McAllan's analysis, 'it is clear that it is Indigenous relations with the land that threatens possessive tenure and relations' with the result that the possessive logic of whiteness must deny 'community', for example by deriving a false paternal legitimacy for the Northern Territory intervention by representing Indigenous communities as lacking in self-determination and property entrepreneurialism. The 'appropriative power of possessive whiteness', for McAllan, requires the denial of community across incommensurable differences, imposing instead 'the law of the same'.

Julie Browning shifts the focus from whiteness and paternalistic coercion to questions of gender, violence and incarceration. Her paper analyses policies and practices of immigration detention in Australia through the lens of hypermasculinity and the 'state of exception' (Agamben 1998), arguing that 'gender is a dimension to both the rationale for detention and the forms of struggle against incarceration'. Browning draws on extensive interviews with former detainees in describing immigration detention centres as 'a space of exaggerated masculinity' in which 'violence is entrenched and the willingness to fight and the capacity for combat are measures of self-worth'. In the 
hypermasculinised space of immigration detention, protest actions, undertaken primarily by male detainees, seek both to effect change in decision-making and also to reposition the male detainee as an active masculine subject. For Browning, collective protest among detainees in immigration detention occurs on the threshold between life and death analysed by Agamben as 'bare life', yet suggests that the conditions of exception are never total and, contra Agamben, struggle is not pointless.

Lana Zannettino's paper places questions of immigration detention within debates around hybridity and national identity which developed prior to the 'war on terror', linking attention to asylum seekers reduced to 'bare life' back to questions around hijab and everyday negotiations of identity. Zannettino analyses three well-known Australian novels written for teenagers - Melina Marchetta's Looking for Alibrandi (1992), RandaAbdel-Fattah’s Does my Head Look Big in This? (2005) and Morris Gleitzman’s Girl Underground (2004). Like Browning, Zannettino frames her discussion of immigration detainees as described in Girl Underground through Agamben's theorisations of 'bare life' and the biopolitics of 'the camp'. The novel documents correspondence between the young white working-class protagonists and two young asylum seekers held in the ‘extreme situation’ of detention.

The other two novels focus on young, ethnically-marked women and their negotiations of hybrid identities - signified most clearly by Amal's deliberation on whether, when, where and how to wear hijab in Does my head look big in this? These protagonists are confronted with processes of othering, belonging, inclusion and exclusion. Read together, argues Zannettino, these novels provide an 'implicit pedagogy of race relations in Australia'. These books suggest hopeful possibilities for both hybrid identities, and, in the face of politics of fear and 'exception', 'collaborations of humanity'.

\section{Acknowledgements}

We would like to thank Kevin Dunn and Bronwyn Winter for contributing their time and expertise to a publications workshop for postgraduate and early career researchers at the Not Another Hijab Row conference. Following the workshop six participants took part in a 'mentoring' process whereby they were provided with feedback from senior researchers prior to submitting papers for publication. The mentoring process was supported by a small grant from the ARC Cultural Research network ECR/PG Node. Many thanks to these mentors: Sharon Chalmers, Eva Cox, Jane Durie, Heather Goodall and Penny O’Donnell. We would also like to thank Kiran Grewal, Lindi Todd and Jonathan Marshall for their invaluable assistance in bringing this special issue to fruition. 


\section{Bibliography}

Abu Odeh, L (1993) 'Post-colonial feminism and the veil: Thinking the difference', Feminist Review 43: 26-37.

Agamben, G (1998) Homo Sacer: Sovereign Power and Bare Life Stanford University Press, Stanford California

Ahmed, L. (1992) Women and Gender in Islam, New Haven: Yale University Press.

Ayotte, Kevin J. and Husain, Mary E. (2005). Securing Afghan Women: Neocolonialism, epistemic violence, and the rhetoric of the veil. NWSA Journal, 17(3), 112-133.

Bouma, G. D. and J. Brace-Govan (2000) 'Gender and Religious Settlement: Families, hijabs and identity', Journal of Intercultural Studies 21(2): 159-175.

Butler, C. (1999) 'Cultural Diversity and Religious Conformity: Dimensions of social change among second-generation Muslim women' in Ethnicity, Gender and Social Change, R. Barot (ed), New York, Palgrave: 135-151.

Dreher, T (2006) Whose Responsibility?: Community anti-racism strategies in NSW after September 11, 2001 UTS Shopfront Research Monograph Series No 3

Dreher, T. (2003) 'Speaking up and talking back: News media interventions in Sydney's 'othered' communities', Media International Australia incorporating Culture \& Policy, vol. November, pp. $121-137$.

Dreher, T., Simmons, F. (2006) 'Australian Muslim Women's Media Interventions', Feminist Media Studies, vol. 6 .

Dwyer, C. (2000) 'Negotiating Diasporic Identities: Young British South Asian Muslim Women', Women's Studies International Forum 23(4): 475-486.

Ferguson, M.L. (2005) “"W” Stands for Women: Feminism and Security Rhetoric in the Post-9/11 Bush Administration’, Politics and Gender 1(1): 9-38.

Ferguson, M. L. and L.J. Marso (eds) (2007) W Stands for Women: Hoe the George W Bush Presidency Shaped a New Politics of Gender Duke University Press, Durham and London

Ho, C. (2007) 'Muslim women's new defenders: Women's rights, nationalism and Islamophobia in contemporary Australia', Women's Studies International Forum, vol. 30, pp. $290-298$.

Ho, C. \& Dreher, T. (2006) 'Where has all the anti-racism gone?'. New Racisms/New AntiRacisms conference, Sydney University

MacLeod, A. E. (1992) 'Hegemonic Relations and Gender Resistance: The new veiling as accommodating protest in Cairo’, Signs 17(3): 533-557.

Moreton-Robinson, A. (2006) 'Towards a new research agenda? Foucault, Whiteness and Indigenous sovereignty’ Journal of Sociology Vol 42 (4) pp 383 - 395

Perera, S. (2006) 'Race Terror, Sydney, December 2005’ Borderlands ejournal Vol 5, No 1

Poynting, S and G Noble, P Tabar, J Collins (2004) Bin Laden in the Suburbs: Criminalising the Arab other Sydney Institute of Criminology Series, Sydney 
Samad, Y. (2004) 'Muslim Youth in Britain: Ethnic to Religious Identity', paper presented to Muslim Youth in Europe: Typologies of Religious Belonging and Sociocultural Dynamics, Edoardo Agnelli Centre for Comparative Religious Studies, Turin.

Timmerman, C. (2000) 'Muslim Women and Nationalism: The Power of the Image', Current Sociology 48(4): 15-27.

UMWA (United Muslim Women Association) (2005) 'Pro-Hijab Campaign, online: <http://www.mwa.org.au/prohijab.htm>, updated: 26 October 2005.

Young, I. M. (2007) 'The Logic of Masculinist Protection: Reflections on the current security state' in Ferguson, M. L. and L.J. Marso (eds) W Stands for Women: Hoe the George W Bush Presidency Shaped a New Politics of Gender, Duke University Press, Durham and London, pp 115 - 140. 